This item was submitted to Loughborough's Research Repository by the author.

Items in Figshare are protected by copyright, with all rights reserved, unless otherwise indicated.

\title{
'The Day the Flame Came to Town': the Olympic flame, symbol, community and commodification
}

\section{PLEASE CITE THE PUBLISHED VERSION}

http://dx.doi.org/10.1123/ssj.2014-0093

\section{PUBLISHER}

(c) Human Kinetics

\section{VERSION}

AM (Accepted Manuscript)

\section{PUBLISHER STATEMENT}

This work is made available according to the conditions of the Creative Commons Attribution-NonCommercialNoDerivatives 4.0 International (CC BY-NC-ND 4.0) licence. Full details of this licence are available at: https://creativecommons.org/licenses/by-nc-nd/4.0/

\section{LICENCE}

CC BY-NC-ND 4.0

\section{REPOSITORY RECORD}

Maguire, Joseph, Jack Black, and Becky Darlington. 2019. "'the Day the Flame Came to Town': The Olympic Flame, Symbol, Community and Commodification”. figshare. https://hdl.handle.net/2134/21158. 


\section{'The Day the Flame Came to Town': The Olympic Flame, Symbol, Community and}

\section{Commodification}

In contrast to the Torch / Flame Relay demonstrations in London, Paris and San Francisco that preceded the Beijing Olympic Games, the relay around the UK was not marked by such conflict. Indeed, surveys of different countries' global influence showed that the UK, rated positively at 55\%, climbed from fourth to third place in positive views since 2012, more than for any other country (Globescan / BBC, 2013) ${ }^{1}$. This increase was attributed to the Queen's Jubilee and 'the Olympic effect' (Globescan / BBC, 2013). Yet, there were contentious identity politics at stake in this Flame Relay, which were worked out at national and international levels - the internal debate within the UK regarding the upcoming Scottish independence referendum and the visit of the Flame Relay to the Republic of Ireland being illustrative examples. In this article, attention is given to the visit of the Flame Relay to Loughborough, a small market town in England. We do so in order to critically assess both the symbolism and commodification of the Flame Relay and how this is worked out at community level ${ }^{2}$.

Questions concerning the function and consumption of global sport and the positive and negative features of hosting mega-events in general, and the Olympic Games and Flame Relay in particular, permeated the sporting, political and academic debates in the lead up to the London 2012 Olympic Games. Representatives from the sports-medical-industrialcomplex (Maguire, 2014) - an amalgam of sporting / academic / economic / and media interests - made claims regarding the perceived impacts and effects of the Olympic Games and Flame Relay that focused exclusively on positive benefits: social cohesion, enhanced participation, health benefits, pride, prestige and a renewal of national identity (see also Maguire, 2005). In this instance, as the UK Tourism Board (BBC, 2011) noted, the Games

\footnotetext{
${ }^{1}$ Following MacAloon (2012a) here we will refer to the Flame / Torch Relay as the Flame Relay.

${ }^{2}$ We would like to thank the two anonymous reviewers for their helpful comments.
} 
were helping to put the 'Great' back into Britain and, as the London Olympic Organising Committee (LOGOC) claimed, they were revitalising sporting endeavour at a local, community level. Others claimed that the Games would enhance intercultural communication both within the UK and across nations, promote mutual respect and remind people of the symbolic value of such civic rituals and ceremonies (BBC, 2012; Campbell, 2012). But, do they?

\section{The Flame Relay: Symbol and Commodity}

Elevating the Olympic Games beyond all other global events and organizations, the historically invoked essence of Olympism remains the marker of distinction that separates the games from the rest of the sports calendar (Wamsley, 2004). From the writings of de Coubertin to the Olympic Charter, and the promotional rhetoric of today, the 'fundamental principles' of Olympism offer not only a guiding philosophy for the games, but a moral philosophy of life (Segrave, 1988; Wamsley, 2004). Constructed around the three core values of excellence, friendship and respect, Olympism 'draws together sport, culture and education in the aim of creating a harmonious balance between body, will and mind' (The Olympic Museum, 2007: 2). Emphasizing the role of sport in world development, international understanding, peaceful coexistence and social and moral education, the Olympic Games are festivals for the celebration of these officially expressed global values and ideals (Loland, 2004; Spaaij, 2012). In the face of such grand claims, however, the idea of highly specialized, performance sport as a sphere for the promotion of peace, culture, and education has been challenged. The growing disparity between the Olympic rhetoric and reality has become an increasingly prevalent form of critique (Crowther, 2004; Loland, 2004; Milton-Smith, 2002).

Though the Olympic Games themselves have thrived in the current commercial and professional world of top level sport to become one of the most popular products on the entertainment market, the Olympic ideology meant to undergird the entire movement has 
arguably not secured the same levels of success (Loland, 1995; Segrave, 2000). Herein, the Olympic Flame Relay in the lead up to the games has been characterized as a significant ritual in the promotion of the Olympic Movement. A ritual, rather than a sports event, the Olympic Flame Relay is arguably 'more sensitive to the values of Olympism than the Olympic Games' (MacAloon, 2012c: 666) and has become the opposite or 'the anti-dote, to everything the Olympic Games themselves have become' (MacAloon, 2000: 24). With the relative absence of elites, the Olympic Flame symbolically emphasizes the connection between Olympism, ordinary citizens, and local contexts (MacAloon, 2012a). Rich in symbolism the flame is said to invoke sacred forces that effect social and spiritual transformations, offering a sense of continuity with the 'golden age' of classical Greek heritage. Underlining the claimed connection between the Ancient and Modern Games, the flame is kindled in front of the ruins of the Temple of Hera in Olympia using the sun's rays to ensure its purity (Olympic Charter, Rule 13). Under the responsibility of the Organising Committee of the Olympic Games, the flame is then carried by relay to the host city to 'herald the Olympic Games and transmit a message of peace and friendship amongst peoples' (The Olympic Museum, 2007: 2).

Despite these historical referents, the Flame Relay is relatively recent, making its inaugural appearance at the 1936 Berlin Olympics. The modern origins of the Flame Relay situate it amidst wider, and often competing, political agendas that provided different meanings for people. While heralded as the symbolic link between the Games' ancient home in Olympia, Carl Diem's ${ }^{3}$ choice of the flame was part of a wider campaign of Nazi propaganda during the 1936 Olympics (Large, 2007; Mackenzie, 2003). Following Hitler’s belief that the Aryan race was of 'ancient Greek stock', the flame was used to symbolize the connection between Germany and the Olympic's ancient beginnings in Olympia (Cahill,

\footnotetext{
${ }^{3}$ Carl Diem (1882-1962) was the Secretary General of the Berlin Olympic Games.
} 
1999 see also Slowikowski, 1991). The flame’s inclusion in Leni Riefenstahl’s 1938 film Olympia helped to combine Olympic ideology with the aesthetic portrayal of Aryan sportsmen and women (Large, 2007; Mackenzie, 2003; McFee \& Tomlinson, 1999). The flame's use as a 'political' symbol continued post-1936, with cities and governments using it to promote themselves. For example, the Olympic Games to Mexico City (1968) were the first games to be held in Latin-America as well as the first to take place in a developing nation (Witherspoon, 2008). Such rhetoric was avidly capitalized upon in the flame's marketing, with the relay symbolizing the link between the Latin-American and Mediterranean civilizations (IOC, 2012).

In addition, Sydney's decision to begin the 2000 Olympic Flame Relay at Ayer's Rock (Uluru) 'a sacred site of the [Aboriginal] indigenous population’ (IOC, 2012: 3), was given further credence by the aboriginal athlete, Cathy Freeman, who was awarded the honor of lighting the Olympic cauldron during the opening ceremony (White, 2013). Enveloped in a wider political debate concerning the Australian government's treatment of its aboriginal population, 'the choice of Freeman [...] to light the Olympic Flame was a climax to the theme of reconciliation' which was constructed by the Sydney organizing committee (Rowe \& Stevenson, 2006: 197). Together, both the Sydney Olympics and its accompanying relay provided the Australian government with the opportunity to define its national image alongside the history of aboriginal heritage and culture (White, 2013). Undoubtedly, such an image was, at the time, an important part of Australia's attempts to present a positive national image, and a somewhat reinvented national history, in front of a watching global audience (White, 2013).

More recently, the 2008 Beijing Olympics continued this trend with Beijing's motto of 'One World, One Dream', which sought to actively situate Beijing within a wider international context as well as highlight China's successful emergence as a global super 
power (Xu, 2006: 90). As such, Xu (2006) highlights that the Beijing Games occurred at 'a critical juncture' in world and Chinese history, particularly in regards to China's 'grand socioeconomic transformation’ (2006: 90). Indeed, this was echoed by Beijing’s International Flame Relay - the longest distance a Flame Relay has travelled.

In fact, the last time the flame had been seen in Britain was during the Beijing Flame Relay. The protests which met the flame during its London phases were widely covered within the British and Western media (Horne \& Whannel, 2010). Indeed, the protest groups highlighting China's human rights records, the guarding of the Olympic Flame by the Chinese 'flame attendants' and the attempts to grab the flame during its journey, were scenes that resonated throughout the media's coverage of its international journey (BBC, 2008; CNN, 2008; Lewis \& Kelso, 2008; Walker \& Batty, 2008). Horne \& Whannel (2010) suggest that 'any discussion of how a sports mega-event has been represented- visually, aurally or in print- raises questions of selection, representation and meaning' (2010: 760). Accordingly, research on the 2008 Athens-China flame handover found that media techniques and discourses were complicit in depoliticizing China's hosting of the games, focusing instead on the idealized representation of the flame and its constructed symbolism (Panagiotopoulou, 2010). More importantly, this occurred despite demonstrators protesting throughout Liu Qi’s (head of the Beijing Olympic Organizing committee, BOCOG) speech (BBC, 2008). As a result:

The more or less unknown case of Tibet did not directly interest the majority of the Greek population, which preferred to identify with an idealistic interpretation of the ceremonies and the message of the games (Panagiotopoulou, 2010: 1450)

Whereas the Greek media aimed to focus on the 'idealistic interpretation' of the flame and the ceremony (see Panagiotopoulou, 2010), Wamsley \& Heine (1996) identify how the media 
coverage of the 1988 Calgary Winter Olympics focused on increasing community pride before, during and after the city's hosting. In such instances, a steady stream of mediated information was encoded through a number of multi-media platforms that helped to portray Calgary, and its citizens, as 'globally' minded (Wamsley \& Heine, 1996). As a result, 'Calgarians became active consumers of the Olympic experience they themselves helped to produce’ (Wamsley \& Heine, 1996: 86). In doing so, 'Olympic ideologies came to be accommodated or, perhaps more appropriate, incorporated in practice, through personal and local involvement and affiliation with the Games’ (Wamsley \& Heine, 1996: 82).

Despite the Flame Relays' media coverage many people do not know that the Olympic Movement is purportedly dedicated to universalist principles of peace and reconciliation; fewer still are aware of the philosophy of Olympism and the principles that serve to underpin it (Baker et al, 2012; Segrave, 2000). Even the best creative efforts of leading advertising agencies working with the IOC in a specific 'Celebrate Humanity' campaign seemed unable to reach audiences in the way that the movement suggested (Maguire et al, 2008a). Employed as a strategy to deflect criticism of the Olympic Movement and to add value to the Olympic brand, advertising in the British press revealed little incorporation or emphasis of themes relating to Olympism (Maguire et al, 2008a). Acting as 'blendwork', under the influence of extreme commercialization, Olympism as a concept has been debased to ‘empty advertising clichés’ (Milton-Smith, 2002: 138).

Indeed, the commodification of the Flame Relay is frequently discussed in contrast to respecting the sacredness of the ritual (Yalouri, 2010). Because of the perceived respect and goodwill that the ritual promotes, and the ensuing exposure of the brand name, corporate sponsors and commercial companies have increasingly used the Olympics and the Flame Relay as a platform to promote their brands (Horne \& Whannel, 2010). Analyzing the organizational and managerial processes that shape the public experience of the Olympic 
Flame Relay under the emergent 'world's best practices' model adopted by the IOC in 2004, several scholars (Amelidou, 2012; MacAloon, 2012a, 2012b, 2012c, 2012d; Spiropoulos, 2012; Thanopoulos, 2012) have recently highlighted the power struggles evident among stakeholders and sponsors, and efforts to preserve the ritual from the spectacle of the Olympic sports industry and 'media-sport complex’ (Maguire et al, 2008b).

The ritual and symbols depicted as part of the relay have arguably received a higher level of exposure through their association with sponsorship arousing interest in and respect for the Olympic Games and the ideals of Olympism. Nevertheless, this exposure puts in jeopardy the claimed spiritual and community element that verifies the Olympics as a social movement, and also ‘trivializes and tastelessly trashes’ (MacAloon, 2012c: 655) the relay as ritual. On various occasions in 2004, the commercial aspects appeared to outweigh the spiritual, as the marketing intruded on the experience of both running with and witnessing the passage of the flame (see Amelidou, 2012). Waiting crowds were undoubtedly distracted by the sponsors' self- promotion activities, with some missing the arrival of the torchbearer in preference for staying in line for the branded memorabilia that was being given away (Amelidou, 2012; MacAloon, 2012c; Spiropoulos, 2012).

Notwithstanding this, MacAloon, (2000) in chronicling the commitment of the thousands who volunteer or turn up to witness the Flame Relay, cites this as evidence of its significant transformative dimension. In addition to its traditional, sacred, and religious significance, participation in this 'mass ritual' (MacAloon, 1999) is seen to deliver important meaning for communities in terms of social and cultural benefits (Cahill, 1998). Memories of the event can be central in instigating pride and building unity and promoting sports at the community level. This, it is claimed, may also have economic impact on the host community (Cahill, 1998). According to MacAloon (2012c), the symbolic power of the Flame lies in its 
capacity to join local with host-country national sentiments and with the international meanings of the Flame Relay and traditions. As MacAloon (2012a) observes:

The general absence of spoken or written texts offering any official exegesis and the relative paucity of media commentary - most of it after the fact - make the Olympic flame a particularly open signifier. It not only permits, it invites differential meaning-making, whether on the personal or cultural levels. No one tells you, except in the most abstract and generic ways, what the Olympic flame is supposed to mean, and therefore you are freer to make it mean for yourself and your group according to your own cultural codes. (2012a: 585)

But is this so? Were the people we observed and interviewed 'free' to interpret the symbolism of the Flame or where certain meanings already mediated for them? While the Olympic Flame may have unique meaning to the host nation and the local communities through which it passes, each have their own agendas, not always related to the ideals of the Olympic Movement, nor necessarily a harmonious or peaceful affair (Cahill, 1999). The domestic route which was selected for the London 2012 Games was notable for its lack of protest across the UK. Instead, the Flame provided an opportunity for Britons to support the London Games as well as take part in the wider Olympic spectacle, many who were unable to obtain tickets for the Game’s events (Majumdar \& Mehta, 2010). Providing a greater opportunity to be involved, according to MacAloon (2012c) 'there are perhaps 10 times more live viewers for the Olympic Flame Relay than ever see Olympic sports events face-to-face’ (2012c: 651).

Taking the above into consideration, it is clear that the Olympic Games and, for the purpose of this research, the Flame Relay, involve a plethora of complementary and competing narratives (Horne \& Whannel, 2010). As such: 
Some would see the division between the idealists, who are expressing internationalism, sentimentalism, global solidarity, and merchants, who are focusing in the event as a showcase for the global sports entertainment industry, as a major fault line in the contemporary Olympics. (Horne \& Whannel, 2010: 762)

With no global consensus as to the physical and moral qualities that underlie sport, nor the ways it is said to promote peace (MacAloon, 1996), the high level of generality and vacuity in articulations of Olympism, render the concept widely open to interpretation and constant redefinition according to the changing social order and global sports system (Cashman, 2004; Wamsley, 2004) ${ }^{4}$. Continually updated to fit with the changing social climate, rather than adhering to a 'universal' philosophy of sport / life, the unclear and changing nature of Olympism can be more accurately understood as the result and projection of specific patriarchal, Western, and elite social developments (Donnelly, 1996; Eichberg, 1984; Maguire et al, 2008a). Moreover, despite Olympism's associations with the notions of international understanding, equality, and mass participation, the modern Olympics themselves have, since their inception, been class based and exclusionary (Crowther, 2004; Donnelly, 1996; Eichberg, 1984; Maguire et al, 2008a). There are many who find the Olympic ideology fraudulent, fallacious, amoral and illusory, used only in the search for power, prestige and profit (Loland, 1995; Segrave, 2000), representing a 'metaphorical empty flask to be filled by the next political, economic, educational opportunist' (Wamsley, 2004: 232).

In contrast, Yalouri, and others (Bale and Christensen, 2004; MacAloon, 1992) suggest that we should avoid seeking a deeper meaning or the ultimate truth behind Olympic ideology, ritual and symbols. Rather, comprehension of the attraction exercised by the

\footnotetext{
${ }^{4}$ Even the central narrative of Olympism is unclear. Here, we are guided by the definition provided by Segrave (1988).
} 
touring flame, and the emotions it stirs, requires exploring its 'malleability and its capacity to become transformed, multiply interpreted and experienced, used and adjusted to different historical and socio-political situations' (2010: 2155). However, the flame’s 'capacity’ to be 'transformed', 'interpreted' and 'experienced' rests largely upon the flame's political and commercial significances as well as how it is constructed, framed and represented within the accompanying media coverage. In other words, in order to understand the Flame Relay as both an Olympic ritual and a commercial, political and media spectacle, an analysis is required of both how the flame is experienced and how it is mediated. With this in mind, an interdependent analysis of the lived experience and mediated and commodified construction of the Flame Relay can help to provide an understanding of it 'in the round' (Roche, 2000).

\section{Making Sense of the Day: Some Methodological Observations}

The use of many different theories and methods to analyze the modern Olympic Games and its status as a vehicle of 'Olympism' opens up a gap 'between the multiple hybrid complexities of lived experience and the symbolic constructions of media representation' (Whannel, 2008: 253). Investigating one of the major 'faultlines' forming the contemporary Olympics, the Flame Relay and its representation offer a substantive case study through which to examine the transmission of 'Olympism' and the broader process of commerce in which the 'message' is immersed. This paper is part of a broader project examining aspects of the Flame Relay as it travelled across the UK. In addition, Poulton and Maguire (2012) have focused on the phenomena of 'Plastic Brits' - examining the recruitment of foreign nationals into the GB team and wider questions of identity, authenticity, provenance and the changing nature of British society. Informed by a process sociology perspective (Maguire, 2005; 2013), our particular focus is one day in the journey of the flame, and, by combining fieldwork, interviews and media analysis coverage of the event, arguably allowed for a better understanding of the spectators' perceptions of the Flame Relay, the values and significance 
underpinning the relay, and how media representations compare to and / or influence what happened in the town's streets. Thus, our analysis is mindful of both the flame's 'emotional' aspects in the moment, and its constructed media representation.

Specifically, the local newspaper, Loughborough Echo, was collected for analysis. In addition, our focus was on conducting short interviews with people, (49 in total), who had gathered to watch the Flame Relay. The age ranged from late teens to people in their late 80's, (though mostly middle-aged). Men and women were evenly represented. While respondents were predominantly white, ethnic South Asian (Indian) and Chinese were also interviewed. These people were predominantly local, though some came from Nottingham and further afield, including Scotland and Hungary. The large number of school children, who composed the majority of the crowd in various sections, were not interviewed ${ }^{5}$. The interviewees were approached before, during, and after the flame had travelled through the town center. After explaining who we were and obtaining verbal consent for their engagement in the research, short semi-structured interviews were conducted, guided by a series of questions pertaining to what people knew about Olympism and the flame; why they were attending the relay; what they thought about the relay as it had tracked its way around the UK in general and Loughborough in particular; what effect the day might / did have on them and the local community; and what impact the Flame Relay would have on the UK as a whole. The interviews were voice recorded, transcribed verbatim and later analyzed for themes. In addition, in order to capture the image and sound of the day, the three researchers made field observations ${ }^{6}$. One of the researchers has lived in the town since 1988 and the other two researchers have been resident for some 6 years. As such, we knew the location, the place and the space in which the Flame Relay would travel.

\footnotetext{
${ }^{5}$ Consideration of the school children's responses, while important, proved too difficult to undertake due to both ethical and practical reasons, the latter concerning the fact that they were still in a 'school environment'.

${ }^{6}$ In addition, the researchers took some 200 plus photographs of the town centre and its immediate vicinity, but this data is not included here.
} 
In addition to the fieldwork data collection, a qualitative thematic content analysis (Berg, 1995) of the local weekly newspaper was employed to examine what was highlighted and what was omitted from the mediated coverage as compared to that observed on the ground. Confronted by this 'two-way traffic', both between the different modes of analysis, and between theoretical insight and empirical particulars, Hall's (2006) approach to the production, dissemination and interpretation of media messages was drawn upon in order to capture the interplay between media representations and fieldwork observations on the day.

Taking into account the production, circulation, use and reproduction of the media as autonomous and interdependent steps, this model involves both the encoding of meaning in the message in a way that apprehends the members of the audience, and it's decoding as comprehensible to the audience for interpretation (Hall, 2006). Thus, acting as both the 'source' and the 'receiver' of the mediated message, attention was given to how the media represented the day, in comparison with how the audience read and articulated what they saw, heard and knew about the flame.

\section{The Flame Relay and the UK}

Spanning 78 days from the $10^{\text {th }}$ May to $27^{\text {th }}$ July 2012 (including the relay in Greece), 8,000 torchbearers carried the flame to within an hour of 95 percent of people in the UK (The Olympic Torch Relay, 2012). For the IOC, such narratives fit comfortably with the flame’s constructed symbolism allowing 'people from all over the world to discover the history and culture of the host city and country' (IOC, 2012: 2). Accordingly, while coinciding with Olympic values pertaining to 'the harmonious development of humankind' and the promotion of a 'peaceful society' (IOC, 2011: 10), the 2012 Flame Relay aimed to shine 'a light on the whole of the UK' providing a message of 'peace, unity and friendship' (LOCOG, 
London2012.com ${ }^{7}$ ). With a strong focus on the nation's youth in line with the commitments made during the 2012 candidature, the theme of the relay was 'Moment to Shine' (The Olympic Torch Relay, 2012: 6). But, whose moment was it to shine?

There were three commercial partners chosen for the Flame Relay; the South Korean electronics firm Samsung, the UK bank Lloyds TSB, and the soft-drinks company (and longstanding Olympic sponsor) Coca-Cola (Crowther, 2004). Each sponsor was clearly visible throughout the flame's route, providing memorabilia in the form of flags, whistles, and free bottled drinks emblazoned with the sponsor's and Olympic logos. The IOC has continually defended its relationship with commercial partners, and the prevalence of commercial partners and transnational sponsors has, since the 1980's, formed part of a wider process of international commerce and the development of the sports medical industrial complex (Maguire, 2011).

In the case of our empirical focus, this wider context was also apparent. Part of the sports medical industrial complex are research and performance centres of excellence such as those based at UK universities. Our focus was Loughborough, a town in which the university is a major employer and has a significant economic, cultural and social impact on what is but a small market town located in the East Midlands of England - between the cities of Nottingham and Leicester. Loughborough University is also no exception to the sports medical industrial complex model. Indeed, the university was the staging base for the British Olympic team, its Sport Development Centre staff were active in the preparation of individuals and teams on campus, and various scientists and academics were co-opted to ensure success in preparation and performance terms on and off-field. Several students were in the national team, and all team kit would be distributed from the university.

\footnotetext{
${ }^{7}$ LOCOG - the London Organizing Committee of the Olympic Games See http://www.london2012.com/torchrelay/about/
} 
Media coverage was handled by the PR office of the university. Security measures placed the campus into a form of lock-down with enhanced surveillance and identification measures introduced, and staff issued with guidelines in the event of suspicious phone calls or seeing unfamiliar faces. In addition, the university has an Olympic-focused research centre, the Centre for Olympic Studies and Research (COSAR) and when the Flame Relay travelled through the campus the current Director of COSAR was among university personnel to carry the Torch. The hosting of the London Olympic Games and the impact on and by Loughborough University is not our concern here but is worthy of further study. Rather, our attention is focused on the people and the town of Loughborough. Stressing the connection between town and gown, Mike Hay, then the director of the Team GB preparation camp at Loughborough University, observed:

And I'm sure the crowds will be out in Loughborough, as they have been all along the route. The response has really been extraordinary...The people of Loughborough are very conscious that we are all here in the fantastic facilities at their university, and I hope they're proud about that. ${ }^{8}$.

This is the local context for our focus on one of the 78 days of the relay that provides an opportunity to test the claims and counter claims regarding the meaning and impact of the Flame. Before examining people's accounts of the flame and their experience of it, the following section will explore the local mediated construction of the event.

\section{A 'Staggering’ Occasion: Local Newspaper Coverage of the Flame Relay}

\footnotetext{
${ }^{8}$ See http://www.guardian.co.uk/sport/2012/jul/03/torch-relay-loughborough-university-team-gb
} 
Editions of the local newspaper, the Loughborough Echo were selected for analysis ${ }^{9}$. This included pre (29/06/12) and post (06/07/12 \& 13/07/12) coverage of the event. The press analysis examined how the Loughborough Echo constructed the day's event and how the attending public were represented. Ghang (2003) notes that 'the news media constitute a major public venue through which a given society's particular vision of reality is narrated and conveyed to its members as a form of social knowledge’ (2003: 118). Accordingly, exploring how the press constructed the event and the attending public would allow us to consider how this 'vision of reality' (Ghang, 2003: 118) stood alongside interviews and fieldwork observations of the day and the 'lived experience' (Dayan \& Katz, 1992; Dekavalla, 2012; Wardle \& West, 2004).

In many respects, the events of the $4^{\text {th }}$ July 2012 echo Dayan \& Katz's (1992) analysis of the 'media event'. The Loughborough leg of the Flame Relay incorporated a live public event that was non-routine, was organized by a larger authority (in this instance LOCOG and the local Charnwood Borough Council) and was watched and attended by audiences along the Flame's route and online, via the BBC’s live relay coverage. More significantly, however, was the extent to which these characteristics were brought together in the press's discourse in order to portray the event as an 'historic occasion'. Ashe (2012a) noted that, 'thousands [were] expected to position themselves along the streets of Quorn, Loughborough, Hoton and Wymeswold to witness history being made' (Loughborough Echo, 29/06/12, pg.3 [italics added]). This was continued in the $6^{\text {th }}$ July edition via the headline: 'Town set alight as history is made' (Loughborough Echo, 06/07/12, pg.5). In both instances, the press were able to represent the event as an historic occasion for both the town and its residents. However,

\footnotetext{
${ }^{9}$ Notably across the press's coverage references were made to the 'torch' relay as opposed to the 'flame' relay. Whereas the design of the torch forms an important part of the host nation's Olympic flame relay, with each host nation selecting their own torch design, the press's focus on the 'torch' as opposed to the 'flame' provides a notable signification of how the relay is viewed by the host nation. That is, while MacAloon (2012a) has highlighted the centrality and importance of the Olympic 'flame', the Loughborough Echo's coverage served to highlight the 'torch'.
} 
further information regarding the day's 'historical' relevance was noticeably absent. Instead, legitimacy was predicated on the event's construction as a dramatic occasion and stylistically constructed (Ebbrecht, 2007). As Getz (1998) notes the significance and constitution of the 'special event' varies between stakeholders:

From the point of view of the consumer, or audience, a special event is an opportunity for a leisure, social or cultural experience outside the normal range of choices or beyond everyday experience. From the organizer's point of view a special event is any one-time or infrequently occurring event outside their normal programme of activities. (1998: 410-411).

From our press analysis we can further add to Getz's (1998) description, by suggesting that from the point of view of the media, a special event is also one that requires a sense of historical significance. This historical significance is one that is constructed not through historical fact but through a dramaturgical performance of history-in-the-making that is much relied on by the event's carnival atmosphere (Ashe, 2012a). A festival-like program of events and a carnivalesque atmosphere was emphasized within the press's coverage. In the week before the Flame Relay, a headline read: 'Expect Carnival atmosphere on the torch route' (Ashe, Loughborough Echo, 29/06/12, pg.7). The article noted that, 'A carnival atmosphere will welcome the Olympic torch through Loughborough town centre' (Loughborough Echo, 29/06/12, pg. 7), helping to actively construct a sense of occasion. The article also described the flame's supporting events: 'A bugler will be stationed at the entrance to Market Street to provide a fanfare to welcome the Relay into Loughborough town centre' as well as 'quad bike procession, golden stilt walkers, [and] a dance troupe’ (Ashe, Loughborough Echo, 29/06/12, pg. 7). Further descriptions also highlighted the performances of local schools and 1st Loughborough Boys and Girls brigades, who were set to march and perform drills during the day. This information was accompanied by details regarding the best spot to view the 
relay as it passed through the University campus and town centre (Loughborough Echo, 29/06/12). In such instances, the press were able to locate their own centrality by distinguishing themselves as a central factor in the day’s promotion (Couldry, 2003).

Certainly, while references to the 'carnival' atmosphere and reports of the event's associated performances all helped to add to the event's significance, what became apparent from the press's discourse was that this was a significance that was largely organized by the local council and by the press's publicity. Whereas the day's 'main event' was the arrival of the Flame Relay as it passed through the University and the town centre, it was evident that further activities and the prospect of a carnivalesque atmosphere were required in order for the event to hold a greater significance and interest.

In addition to performances by local residents and school children, attempts were made in another article to highlight the opportunities that the event created for local businesses and shop owners in Loughborough. Members of the public and local business owners were quoted for highlighting the benefits that it would bring for local trade (Ashe, 2012a). One member of the public stated that the event 'will be a boost to the town center's firms such as food and drink outlets' (Ashe, Loughborough Echo, 29/06/12, pg.3). Similarly, Stuart Carter, chairman of Loughborough Chamber of Trade, was quoted as saying, 'It's quite exciting. It's nice they’ve chosen us in Loughborough, it helps put little Loughborough on the international map’ (Ashe, Loughborough Echo, 29/06/12, pg.3). It is perhaps a stretch of the imagination to perceive that the flame's arrival in Loughborough was enough to put the small market town 'on the international map', however, such comments confirm the commercial imperatives at work on the day. As Getz notes: 'When festivals and other special events are consciously developed and promoted as tourist attractions, there is the risk that commercialization will detract from celebration; that entertainment or spectacle will replace the inherent meanings of the celebrations' (Getz, 1998: 409). Certainly, amongst all the 
coverage that served to highlight the event's historical significance and the potential economic prosperity it may create, there was no reference to the flame’s wider significance as a meaningful Olympic symbol.

An important part of the 'news narrative' is how particular characters may be employed by the media in order to add to the event's construction (Ghang, 2003). Here, 'characters are social actors identified or portrayed in the news, through which views, ideas, and perspectives may be articulated either directly or indirectly’ (Ghang, 2003: 118). Indeed, Dayan \& Katz (1992) highlight that for a media event to be successful, public support and interest is required. Along those lines the public were constructed as a significant social actors in the media coverage with reference made to the amount of people attending the Flame Relay, often noted to be in the 'thousands"10 (Loughborough Echo, 2012a). Before the event, Ashe (2012a) stated:

Twenty thousand people are expected to line the Torch Relay Route in Charnwood - with around 10, 000 heading into Loughborough town centre alone to celebrate the Olympic Flame passing through next Tuesday (Ashe, Loughborough Echo, 29/06/12, pg. 3).

In the following week's edition this attendance figure was claimed to be much higher. One article byline read: 'STAGGERING: 50,000 lined the route to cheer on the bearers' (Loughborough Echo, 06/07/12, pg. 5). The article added that, 'A staggering total of 50,000 turned out to watch the Torch in Charnwood - just 3,000 less than the relay numbers in Leicester' (Loughborough Echo, 06/06/12, pg. 5). Here, the press served to create a sense of public solidarity and civic integration via references to large amounts of people who had attended the event. Taking this into consideration, one could infer that the public was largely supportive of the event and entirely enthusiastic.

\footnotetext{
${ }^{10}$ It was not stated within the coverage how this attendance had been calculated and based upon our own observations these figures should be treated with great caution.
} 
In the $6^{\text {th }}$ July issue, large sections of the newspaper were devoted to photographs of the day, the majority of which were of the public. This included photographs of people standing alongside the flame's route and photographs of individuals involved in the Flame Relay ${ }^{11}$. Photographs of the public lining the flame's route and reference to the number of people attending the event, along with references to the carnival atmosphere, helped to construct a sense of public support, and which served to portray a united, homogenized, local community.

Yet, this sense of public approval for the occasion was often implied and represented through the use of photographs and by-lines. Short by-lines were provided with each photograph in the $6^{\text {th }}$ July edition, but these were often very brief, were limited to one-line sentences highlighting a rather generic 'excitement' or 'anticipation' for the event. There was, however, a lack of attention to public opinion. While a short section in the $29^{\text {th }}$ June edition quoted members of the public who were going to be taking part in the relay, no attention was given to the opinion of members of the public during or after the event. How then did our own fieldwork and interviews contrast with this media coverage?

\section{Anticipating, Experiencing and Reflecting on the Flame Relay: Excitement, Community}

\section{and Nation}

To give you an impression of the start of the day let us draw on some observations made in our field notes:

We arrive at 0900 at the Town Hall. On the way there I overhear a shopkeeper surprised and disappointed by the 'lack of people' near Bedford Square by the florists. I meet Becky and Jack and we divide parts of the town to scope and interview the crowd. The Town Hall area is loud - a school band plays and a compere is, without success, trying to whip up the crowd's enthusiasm. The

\footnotetext{
${ }^{11}$ Based upon our own experiences of the day it was also evident that these photographs had been selectively chosen. In particular, on certain sections of the route it was evident that the angle of the photograph had been chosen in order to create an inflated impression of the number of attendees.
} 
crowd is quite small, congregated around the music bandstand. Go 50 meters and there are few or no people at all. Over the next hour the crowd line either side of the pedestrian area and town hall square, behind metal barricades, but never more than 3 - 4 deep and mostly 1-2 deep. Without the presence of Loughborough Grammar School (LGS) and Loughborough High School (LHS) pupils there would be a lot less people. In terms of the crowd, the demographic is mostly white, middle aged, though South Asian and Chinese are also present - the former appear locals but the latter may well be university students. Men and women are present, as are, due to the schools, boys and girls - though the latter skew the class composition as LGS and LHS are private schools. Of the locals, most I suspect are respectable working class and middle class. In comparison with market day, the lower working class are not present.

We start to interview those present outside the town hall, by Ashby Square and across from McDonalds. Several themes arise from the responses. Our questions began with probing what people experienced and what significance they felt the Flame Relay had. Echoing the mantra that had appeared in the media, interviewees repeatedly said that seeing the Flame Relay was a 'Once in a lifetime opportunity', that it was 'part of history'. When pressed why, a white woman in her late 30's remarked: 'I'd seen it on East Midlands Today (a local television news program) and just wanted to join in the atmosphere'. For us, this was worthy of note and reinforced the impression that the media had played a role in framing the event in advance of the day itself. Akin to the classic Lang \& Lang (1953) study of how television did not simply report events but created a wholly new view not experienced at the event itself, we wanted to consider the potential or actual mismatch between being on the ground and the media coverage of the day. In addition, we felt that an appreciation of both media coverage and fieldwork / interviews was required. 
In other interviews people reflected on the Flame Relay. A white male in his late 30's observed: 'It doesn't happen very often. It's the Olympic Flame, its heralding the Olympic spirit and the fact that it's coming to Britain. It may not happen for another 50 years and it won't happen in our lifetime so it's a way for people to be included and involved isn't it? For a white Briton in her 50's the Flame Relay was viewed as 'symbolic of the start of the Olympic Games, the eternal flame being shared all across the world, networks across cities' and that it was 'magical, unique [a] lifetime event with wonderful people proudly bearing that golden flame [and a] superb opportunity for us and my grandchildren.' Continuing in this vein she observed: 'it's just really exciting, just to see so many different people, from old, young, mixture of people, just coming along, seeing it cheering as it goes along and ... it's a once in a lifetime isn’t it?'

To be seen as 'taking part in [a] carnival atmosphere' was viewed as 'exciting' that 'makes you feel quite proud'. However, people were less clear as to what the symbolism stood for. Some were 'hoping it's going to be exciting' and were 'desperately hoping that it's not going to be a let-down'. From our observations, the greater sense of excitement was related to the cavalcade of sponsors' vehicles, with onboard officials beseeching people to get in the mood, and feel the excitement. Those whose vantage did not allow the experience of this had to be content with the flame itself ${ }^{12}$ - a much more muted affair - with only the police outriders trying to whip up the cheers of the crowd as the torch-bearer came by.

Despite this, a white man in his 40's, there with his young children, thought that the flame 'signifies the beginning of the Olympics, that's what it means to us, but as far as the history I couldn’t tell you really’. He went on by saying ‘it’s just a nice symbol. There’s not many things these days that encompasses the whole thing...of the Olympics doesn't it?'

\footnotetext{
${ }^{12}$ Due to their size, the procession of sponsors' vehicles was unable to follow the flame along Market Street and Market Place, two of Loughborough town center's main roads.
} 
Observations of this kind anticipated the related theme we wished to explore - the symbol of the flame, the concept of Olympism and the Olympic Games.

\section{Olympism: Imagined and Real}

A white women in her 30 's, with her family all dressed in matching t-shirts as a show of support for her uncle who was carrying the torch for part of the route, remarked that Olympism was 'Done in the spirit of Amateurism. Designed for the common man to achieve what he can'. This family, and their uncle, were unusual. Of all the members of the crowd they were the only ones who we observed having a direct connection to the relay. Indeed, previous and subsequent nationwide media disquiet regarding the relay had centered on the excessive number of sponsored corporate torch carriers. On the day, however, a sense of local pride was evident.

At the same time the over-riding impression was that people knew very little about the concept of Olympism or the history of the Relay. Take the following comments made by a white male in his 20's: 'I can't say I know what the term means but from the Olympian, I don't know if that's similar, but from the term Olympian I see someone who is paramount or peak in their particular discipline'. Note here the link between the concept and performance / excellence - one of but several elements that Segrave (1988) has identified with Olympism. In a similar vein, a man in his 40's, working at the university, observed before the flame arrived: 'We know it's started in Greece, we know it's about global peace and harmony and involvement and collaboration. So it's a meaningful thing. Obviously a few seconds seeing somebody run by with a torch is not very exciting but it's the symbolism of it, that everyone gets involved in you know, part of joining up with people around the world'.

Our overriding impression from the interviews conducted was that people had great difficulty in providing a clear sense of the term Olympism. Local schools - at least in the private sector - did spend considerable class / house assembly time on accounting for each 
Olympic Games since 1896 and some reference was made to what were claimed to be Olympic values. However, little of this appears to have gone beyond the school gates. Typical of this general lack of knowledge were responses such as 'not heard of it at all', 'errr it’s the spreading of ... sportsmanship isn’t it?' and 'Just the Olympic torch ummm going through the town, the country'. Another interviewee, a white 40 year old male local, with a Hungarian background, laughed nervously, and, with slight embarrassment responded when asked if he was aware of any of the values associated with Olympism replied: ' Not really'. While others responded by saying variants of 'that's a difficult question', when asked what the purpose of the relay he answered:

'Umm it's always just the symbol of the Olympics for me, it's kind of, not everyone can go to the opening ceremony so it's kind of a taste of that for everyone else I guess. It went through Scotland and Glasgow where I'm from but I didn’t hang around for it. I'm in the same situation as I am now, if I wait five to ten minutes it will pass but I didn’t care too much then to wait so I just went home’.

This response, and that of others, highlights the multifaceted nature of the responses but also serves as a timely reminder that local and national circumstances can and do contour and shape how the Flame Relay is framed, interpreted and experienced. The Olympic Games that followed was similarly contested, in the context of Scotland, the Scottish National Party (SNP) politicians labeled Scottish athletes as Scotolympians while the largely English press lay claim to the British identity of athletes such as the cycling gold medalist Chris Hoy.

The ethnic identity of local respondents in Loughborough had some bearing on responses. South Asian (Indian and Bangladeshi) respondents differed little in their responses. Chinese students were more reluctant to talk and when they did they chose not to do so as fully as others. Some critical voices were heard. One local English woman in her 
50's, married to a man of Greek descent, observed that Olympism was 'A fancy smancy latter-day word. These words, you know, the people in power make up these words and do they mean anything? ... Probably my thoughts go back to Greece, the birthplace of the Olympic Games, my husband is Greek, so we have been there a lot'.

This emphasis on tradition, on sportsmanship, on amateurism, the flame being the expression of the spirit of the Olympics and the relay being an opportunity for 'this part of the country [to] be part of it as well as London' were part of the dominant narrative. When pressed, however, few, if any, knew what the flame stood for or its associated morals and values. Whereas there was doubt and a lack of clarity regarding Olympism, people hoped that the Flame Relay would have a positive effect on the local community and the town in general.

\section{The Flame Legacy for Loughborough}

Observing the crowd as they gathered in the town center, a white male, in his 20's, observed that the impact would be about: 'Bringing people together, I mean if you look around you today there is [sic] people from all different kinds of faith, all different schools, all different ages, people from 6 to 96 really and I think any event and any activity that brings people together like that and gets conversation going is great for a town. So yeah I think it's good for the community and really good for Britain as a whole as well’.

This theme of bringing people together, that 'unites people on the ground', providing a 'sense of community' appeared as a desire, a wish and a deeply-held need. People wanted the Flame Relay to do this - and looking around they felt that, with 'people enjoying themselves' and 'getting into the spirit of it' this would ensure their wishes would / were coming true. How real or imagined, how deep and long-lasting or shallow and ephemeral such effects may be did not figure as part of their reflections. As a male in his 40's noted: 'I think it's great children have been involved so much in this so that ... young children are starting to 
understand that it has something to do with them and that means you start to get people interested in sports and a community in the future'. People were equally convinced that the Flame Relay would have a positive impact on the perception that outsiders have of Loughborough. Of course, this perception would be mediated and not just based on the small number of non-locals in the crowd.

People acknowledged that there was work to be done. Take the following comment made by the female in her 30's there to support her uncle: 'I think it will surprise people that think Loughborough is a bit rubbish, it's a bit this and that. And maybe they'll see we can put on a good show and might make people feel better about it’. In a similar vein an elderly white lady noted that 'I think it will boost the town because people will come, well we come to Loughborough regularly, but people have probably come just for this and it will give them an idea to come and see what Loughborough is like after this. Because it's got some good shops, two good supermarkets, they've got the town hall, cinema.'

Picking up on the commentary of the compere outside the Town Hall - who had been busy drumming up enthusiasm - we asked interviewees the following: 'The commentary said it was important for the world and important for Loughborough, do you agree?' The middle aged woman, interviewed after the flame had passed responded: 'Yes, I do. I think we need to come together, we need to be more, I don't know, we just need to come all together, especially during this time, with the depression, it's awful.' The perceived impact of the Flame Relay was then not only to tackle people's sense of gloom but also the negative perception that they felt people had of the town. Going beyond the coverage of the day, one member of the crowd noted that 'It's in the news, it's brought up Loughborough's profile again'. Certainly local politicians and the university’s public relations officials were keen to spin the good news.

\section{Corporate Messages, Powerful Brands and a Local Market Town}


While the researchers involved were sensitive to signs of an increased presence of advertising and logos and the distribution of 'free' corporate merchandise associated with the Flame Relay sponsors and The Olympic Partner (TOP) sponsors such as McDonalds, those interviewed seemed to acknowledge these as a taken-for-granted feature of global sport or as part of the price of 'doing business'. Picking up on this theme the following field notes were recorded just prior to and on the arrival of the cavalcade:

As I move around the square towards McDonalds and Baxter Gate the crowd is fair but less than at the Town Hall. Without LGS in Baxter Gate the crowd would be very thin. The LGS have been turned into Union Jack and Samsung carrying adverts. The senior teachers are there but seem oblivious to this - indeed, the Headmaster, who has brought his dog - is also waving the Union Jack / Samsung flag. The cavalcade has arrived and I catch up with it by Halifax Bank - the three main vehicles are all sponsored - Coke Cola, Lloyds Bank and Samsung - the latter has part of the vehicle as a jumbotron - with a glocalised theme to its advertising. It's priceless - 'Samsung welcomes the flame to Loughborough'.

Coke are already there - with a line up for the free giveaways - flame shaped bottles of coke. The crowd are being aroused by the presence of the cavalcade - the compere onboard localize the corporate message and extol the crowd to feel the excitement and to join in the cheering. The music blasts out from the vans. Several people note the importance of the day - the media lines ‘unforgettable experience’ and 'once in a lifetime opportunity’ are mantras said or overheard. The commodification of the town route is there to see, touch, listen to and taste. There are various outlets and levels. The local level includes hawkers / street sellers flogging mostly the rubbish you see at fairs: plastic flames, flags and other cheap stuff. Local businesses have Olympic themes (some 
non-chain shops have put into their windows Olympic theme Flame Relay sponsors adverts).

McDonalds are dishing out free vouchers plus their window display has changed for the day - with much made of their TOP status. The same is true of Lloyds Bank [the following day they are all gone]. Cola-Cola have also coopted local shops to carry their Flame Relay inspired posters, pennants and balloons. The Asian newsagent at Ashby Square tells us they arrived the day before - they appear not to have paid for this and have promised to return later today to take down the bunting. Most people appear happy - they welcome the sponsors, attracted to the giveaways, wait to be photographed on the Coke-Cola London bus, carry the balloons, flags and flame bottles - it’s simply naturalized. The noise, colour and razzamatazz of the sponsors is in strong contrast to the actual flame - which goes by with polite applause and muted excitement, lots of photographs taken and accompanied by cheerleading from the motor-cycle police outriders - drawn from the Metropolitan police.

Despite these observations, most of those interviewed were unaware of the commodified nature of the day or sought to downplay it. A white man in his 40's observed that 'It's not been particularly commercial actually. There's a few street sellers out selling a few union flags, they're not pushing it down your faces'. This man, an off-duty Police Officer, was not alone in his views. Other members of the crowd thought that the cavalcade of sponsors trucks either 'made a better show of it' or that 'It was quite low key. I don't think it was too in your face. Yeah, it was quite low key and about right.'

For some who noted the presence of the sponsors' vehicles and merchandising there was a resigned acceptance. A middle aged woman interviewed after the relay had passed by observed: 'There's a lot of commercial but then that's needed, isn't it. I don't think it's [the 
Flame Relay] been undermined in any way.' Another voice added 'No, I think it's all part and parcel of it. Without one you don't get the other'. These observations, and others like them, highlight an acceptance of and an acknowledged need for the commercial side of the relay. There were few critical voices among those we interviewed. Of the observations made, one thought it a 'bit of a disappointment' and that 'the corporate side is a lot bigger than most people expect' and that the Flame Relay 'has been perhaps a bit too led by the big companies, multinationals and the brands'. One white male, in his 30's, who on speaking about whether this commercial side detracted from the Flame Relay, revealed he was from a university nearby. He then observed:

'Yeah to an extent. I also think it makes a bit of a mockery of it in some senses. You only have to look at Subway and there's two athletes competing in Subway [laughs] er the Olympics talking about what Subway they eat and they almost cartoonise the two athletes...Surely you don't have to get it to the point where the Olympic athlete that should be taking pride of place is secondary to the product'.

\section{Conclusion}

The use of the Flame Relay as a promotional tool for London and the UK (London2012.com ${ }^{13}$ ), as well as for broader goals of peace and friendship (IOC, 2011), engendered a set of narratives that have, to varying degrees, been used by both host nations and the IOC since the Flame Relay’s ‘invention’ during the Berlin Games of 1936 (Horne \& Whannel, 2010). So: what of this relay, and of this day in the journey to London? MacAloon (1992) is undoubtedly right to point to the social significance of civic ceremonies and correct to indicate the need for more fieldwork / ethnographic accounts. In addition, his critique of media accounts is right to suggest that researchers can sometimes overlook the complexity of

\footnotetext{
${ }^{13}$ See http://www.london2012.com/torch-relay/about/
} 
lived experiences. Powerful texts do not necessarily have powerful affects. Yet, the evidence presented here suggests he overstates his critique of media research and does not sufficiently acknowledge how the lived experience of the relay is itself mediated. Mediated accounts of the relay and peoples' lived experience of it are intertwined. In addition, most people have very little knowledge about Olympism or what the symbol stood for. As a local coal / wood merchant some days later remarked, it was all a 'flaming waste of time'. Days, months and over a year later, from our ongoing observations in Loughborough, no-one we have met mentions the day.

How then to make sense of what we observed and what we heard? Is the symbolism and experience real or imagined, authentic or contrived? Are the effects narrow or wide, deep or shallow, long-lasting or as fleeting as the relay itself? MacAloon paints a picture that the ethnographic account is the true way of getting at answers to these questions. While his critique of some media work may be valid, it does not hold true for all such work. Indeed, upon comparing both the media's construction of the day alongside interviews with the public during the event, it is evident that a clear disparity can be observed. Here, the local press served to construct the event as an historic and carnival occasion, widely accepted by the public and thoroughly enjoyed. There were no dissenting voices in the press's pre- and post-coverage - which stood in stark contrast to some of our interviewees. Instead, the press played an important part in promoting the event and imbuing it with significance. The emphasis was on a 'special event' not on Olympism per se. What Olympic narratives did trickle through seemed pre-fabricated, the repeating of headlines and sound bites. The commercial dimension was highlighted as a positive benefit by the press and a taken-forgranted backdrop by the event audience.

In this way the claimed values of Olympism and the flame's symbolic significance were often undermined or entirely ignored. Indeed, this was echoed in many of the 
interviewees' responses. Accordingly, while it is evident that there was a clear disparity between the press's construction and framing of the event and our own experiences of the day, the evidence here suggests that people’s perceptions and experiences of the day were mediated through a combination of event personnel outside the town hall, the flame's corporate cavalcade and the local media. There does appear some evidence of a need for a sense of community, of belonging, of attachment - but in terms of the accumulation of social capital the visit of the Flame Relay appears to have had a shallow and transient impact. Given what we now know was to follow - the success of the opening ceremony, the gold rush of Super Saturday and the feel-good factor of feeling / being British - Loughborough was a staging post through which the corporate, media and sport-medical-industrial-complex travelled.

Despite the evident erosion of its sporting ideals amidst scandals and criticism, the continuing popularity and global success of the Games, and the Flame Relay, are perhaps easier to explain by the spread of an aggressive Western market economy than any spread of Olympism and its related values. This suggests that the Games and the preceding Flame Relay do not need any ideological or ritual elements for them to thrive (Loland, 1995; Moller, 2004). More indicative of the achievement sports ethic (Maguire et al, 2008a), with the cultural significance of its ritual elements ignored in the process of framing and marketing the Flame Relay, most people are left ignorant as to what Olympism and the Olympic Movement purportedly stand for. The changeable and undecided nature of Olympism leaves the construct open to meaning making, into which commodified brand images and messages flow. Akin to previous studies the Flame Relay was firmly placed in a spectacle frame rather than as ritual (Thanopoulos, 2012).

On the day the flame came to town the feeling of togetherness seemed fleeting and illusory, and 'based on group fantasies of grandeur' in which the social significance of the 
Flame Relay changes with its 'mass psychological effects' (Alkemeyer and Richartz, 1993:87; cf. Elias \& Scotson, 1994: 101-105). Depending more than ever on consumption, it can be represented as a 'time-bubble' of a collectively experienced interval, and, on the whole, rather sudden in onset; lasting for a while, and then declining back to banal normality (Collins, 2012). Indeed, these final observation can best be captured by our fieldwork notes that record:

As the Flame Relay disappears towards the train station, on the outskirts of town, the crowds rapidly leave - the school children return to class, the middle-aged focus on shopping and Loughborough returns to its normal humdrum reality - the clean-up operation swings into gear - the crash barriers are being packed away, the litter of the sponsors merchandise picked up and the street hawkers move on - there is no one left to sell the cheap stuff to - the bandwagon, cavalcade and media circus have left town. 


\section{References}

Alkemeyer, T. and Richartz, A. (1993). The Olympic Games: From Ceremony to Show. Olympica: International Journal of Olympic Studies, II, 79-89.

Amelidou, P.B. (2012). The 2004 International Relay: a Greek around the world with the Olympic Flame. Sport in Society, 15(5), 700-712.

Ashe, I. (2012a). '20, 000 expected along the route of torch relay'. Loughborough Echo, 29/06/12, pg.3.

Ashe, I. (2012b). 'Expect carnival atmosphere on the torch route'. Loughborough Echo, 29/06/12, pg.7.

Bale, J. \& Christensen, M.K. (2004). 'Introduction: Post-Olympism?’ In J.Bale \& M.K. Christensen (Eds.), Post Olympism: Questioning sport in the twenty-first century (pp. 1-12). Oxford: Berg.

Barker, D., Barker-Ruchti, N., Rynne, S.B. and Lee, J. (2012) Olympism as education: analyzing the learning experiences of elite athletes. Educational Review,64(3): 369-384.

BBC (2008). China raps Olympic torch protest. BBC News. [Online]. 25 ${ }^{\text {th }}$ March 2008. Available from: http://news.bbc.co.uk/1/hi/world/asia-pacific/7312073.stm. [Accessed: $6^{\text {th }}$ March 2013]

BBC (2008). Clashes along Olympic torch route. BBC News. [Online]. $6^{\text {th }}$ April. Available from: http://news.bbc.co.uk/1/hi/uk/7332942.stm. [Accessed: $6^{\text {th }}$ March 2013]

BBC (2011). London 2012: David Cameron launches 'Great' campaign. BBC News. [Online]. $22^{\text {nd }}$ September. Available from: http://www.bbc.co.uk/news/uk-15019587. [Accessed: $26^{\text {th }}$ June 2014]

BBC (2012). London 2012: How the world saw the Olympic Games. BBC News. [Online]. $13^{\text {th }}$ August. Available from: http://www.bbc.co.uk/news/uk-politics-19238284. [Accessed: $26^{\text {th }}$ June 2014]

Berg, B.L. (1995). Qualitative Research Methods for the Social Sciences Second edition. Boston: Allyn \& Bacon.

Cahill, J. (1998). 'The Olympic Flame: Running Towards Sydney 2000', The Symposium Proceedings of the 4th International Scientific Symposium for Olympic Research. Canada: International Centre for Olympic Studies.

Cahill, J. (1999). Political Influence and the Olympic Flame. Journal of Olympic History, 2932.

Campbell, A. (2012, August 11). London Olympics have redefined how Britain sees itself. CNN. [Online]. $11^{\text {th }}$ August. Available from: 
http://edition.cnn.com/2012/08/11/opinion/alastair-campbell-olympics-opinion/. [Accessed: $26^{\text {th }}$ June 2014]

Cashman, R. (2004). 'The Future of a Multi-Sport Mega-Event: Is there a Place for the Olympic Games in a 'Post-Olympic’ World?’ In J. Bale \& M.K. Christensen (Eds.), Post Olympism: Questioning sport in the twenty-first century (pp. 119 - 134). Oxford: Berg.

Collins, R. (2012). Time-bubbles of nationalism: dynamics of solidarity ritual in lived time. Nations and Nationalism, 18(3): 383-397

CNN. (2008). Torch relay in San Francisco draws massive protest. CNN. [Online]. $8^{\text {th }}$ April. Available from: http://edition.cnn.com/2008/US/04/08/us.olympic.torch/index.html.

[Accessed: $6^{\text {th }}$ March 2013]

Couldry, N. (2003). Media Rituals: A Critical Approach. London: Routledge.

Crowther, N. (2004). The state of the modern Olympics: citius, altius, fortius? European Review, 12 (3), 445-460.

Dayan, D., \& Katz, E. (1992). Media Events: The Live Broadcasting of History. Cambridge; London: Harvard University Press.

Dekavalla, M. (2012). 'Constructing the Public at the Royal Wedding'. Media, Culture \& Society, 34, 296.

Donnelly, P. (1996). Prolympism: Sport Monoculture as Crisis and Opportunity. Quest, 48, 25-42.

Ebbrecht, T. (2007). 'History, Public Memory and Media Event. Media History', 13 (2-3), 221-234.

Eichberg, H. (1984). Olympic Sport - Neocolonization and Alternatives. International Review for the Sociology of Sport, 19(1), 97-106.

Elias, N. \& Scotson, J.L. (1994). The Established and the Outsiders. London: Sage.

Getz, D. (1998). 'Event Tourism and the Authenticity Dilemma'. In W. Theobald (Ed.), Global Tourism (pp. 409-427) (2nd. edit.). Oxford: Butterworth-Heinemann.

Ghang, T-K. (2003). 'Political Drama and News Narratives: Presidential Summits on Chinese and U.S. National Television’. In C. Lee (Ed.), Chinese Media, Global Contexts (pp. 117135). London: RoutledgeCurzon.

Hall, S. (2006). 'Encoding / Decoding'. In M.G. Durham \& D.M. Kellner (Eds.), Media \& Cultural Studies: Key Works, Revised Edition (pp. 163-173). Malden, MA: Blackwell.

Horne, J., \& Whannel, G. (2010). The 'caged torch procession': celebrities, protestors and the 2008 Olympic torch relay in London, Paris and San Francisco. Sport in Society: Cultures, Commerce, Media, Politics, 13(5), 760-770. 
International Olympic Committee. (2011). Olympic Charter. [Online]. Available from: http://www.olympic.org/Documents/olympic_charter_en.pdf. [Accessed: March 6 ${ }^{\text {th }} 2013$ ]

IOC. (2012). Factsheet: The Olympic Torch Relay. [Online]. Available from:

http://www.olympic.org/Documents/Reference_documents_Factsheets/The_Olympic_Torch_ relay.pdf. [Accessed: $6^{\text {th }}$ March 2013]

Lang, K. \& Lang, G. (1953). The Unique Perspective of Television and Its Effect: A Pilot Study. American Sociological Review, 18(1), 3-12.

Large, D. (2007). Nazi Games: The Olympics of 1936. London: Norton.

Lewis, P., \& Kelso, P. (2008). Thousands protest as Olympic flame carried through London. The Guardian. [Online]. $7^{\text {th }}$ April. Available from:

http://www.guardian.co.uk/world/2008/apr/07/olympicgames2008.china2. [Accessed: $6^{\text {th }}$ March 2013]

Loland, S. (1995). Coubertin's Ideology of Olympism from the Perspective of the History of Ideas. The International Journal of Olympic Studies, IV, 49-78.

Loland, S. (2004). 'The Vulnerability Thesis and its Consequences: A Critique of Specialization in Olympic Sport’. In J.Bale \& M.K. Christensen (Eds.), Post Olympism: Questioning sport in the twenty-first century (pp. 189-197). Oxford: Berg.

London 2012. (n.d.). Torch Relay: About. [Online]. Available from:

http://www.london2012.com/torch-relay/about/. [Accessed: $6^{\text {th }}$ March 2013]

Loughborough Echo. (2012a). 'Timeline of when the torch will be passing through'. 29/06/12, pg.7.

Loughborough Echo. (2012b). ‘Town set alight as history is made’. 06/07/12, pg.5

MacAloon, J.J. (1992). The Ethnographic Imperative in Comparative Olympic Research. Sociology of Sport Journal, 4, 103-115.

MacAloon, J.J. (1996). Humanism as Political Necessity? Reflections on the Pathos of Anthropological Science in Olympic Contexts. Quest, 48, 67-81.

MacAloon, J.J. (2000). 'Volunteers, Global Society and the Olympic Movement'. In M. de Morgas, A.B. Moreno \& N. Puig (Eds.), Volunteers, Global Society and the Olympic Movement- International Symposium (pp. 17-28). Lausanne: IOC.

MacAloon, J.J. (2012a). Introduction: the Olympic Flame Relay. Local knowledges of a global ritual form. Sport in Society, 15(5), 575-594.

MacAloon, J.J. (2012b). This flame, our eyes: Greek/American/IOC relations, 1984-2002, an ethnographic memoir. Sport in Society, 15(5), 595-635.

MacAloon, J.J. (2012c). Olympic Flame Relay operations under a 'world's best practices' regime: a conversation with Steven McCarthy. Sport in Society, 15(5), 636-673. 
MacAloon, J.J. (2012d). 'My programme became very strict': a conversation with Athanassios. Sport in Society, 15(5), 674-699.

Mackenzie, M. (2003). From Athens to Berlin: The 1936 Olympics and Leni Riefenstahl's Olympia. Critical Inquiry, 29(2), 302-336.

Maguire, J. (Ed.) (2005). Power and Global Sport: Zones of Prestige, Emulation and Resistance. London: Routledge.

Maguire, J. (2011). 'Civilised Games'?: Beijing 2008, power politics, and cultural struggles. Sport in Society: Cultures, Commerce, Media, Politics, 14(7-8), 1027-1039.

Maguire, J., Butler, K., Barnard, S. and Golding, P. (2008a). Olympism and Consumption: An Analysis of Advertising in the British Media Coverage of the 2004 Athens Olympic Games. Sociology of Sport Journal, 25, 167-186.

Maguire, J., Barnard, S., Butler, K. and Golding, P. (2008b). 'Celebrate humanity’ or 'consumers’: A critical evaluation of a brand in motion. Social Identities, 14(1), 63-76.

Maguire, J. (2013). Reflections on Process Sociology and Sport: 'Walking the Line'. Abingdon; New York: Routledge.

Maguire, J. (2014). Introduction: Making the Case for the Social Sciences of Sport, Exercise and Health. In Maguire, J. (Ed.), Social Sciences in Sport. (pp.1-6). Champaign,IL: Human Kinetics.

Majumdar, B., \& Mehta, N. (2010). It's not just sport: Delhi and the Olympic torch relay. Sport in Society: Cultures, Commerce, Media, Politics, 13(1), 92-106.

McFee, G., \& Tomlinson, A. (1999). Riefenstahl's Olympia: ideology and aesthetics in the shaping of the Aryan athletic body. The International Journal of the History of Sport, 16(2), 86-106.

Milton-Smith, J. (2002). Ethics, the Olympics and the Search for Global Values. Journal of Business Ethics, 35, 131-142.

Moller, V. (2004). 'Doping and the Olympic Games from an Aesthetic Perspective'. In J.Bale \& M.K. Christensen (Eds.), Post Olympism: Questioning sport in the twenty-first century (pp. 201-210). Oxford: Berg.

Panagiotopoulou, R. (2010). Greece: The Olympic Torch Relay in Ancient Olympia- An Ideal Showcase for International Political Protest. The International Journal of the History of Sport, 27(9-10), 1433-1451.

Roche, M. (2000). Mega-events and Modernity. London: Routledge.

Segrave, J. (1988). Towards a definition of Olympism. In J. Segrave and D. Chu (Eds.), The Olympic Games in transition (pp.149-161). Champaign, III: Human Kinetics 
Segrave, J. (2000). The (Neo)Modern Olympic Games: The Revolutions in Europe and the Resurgence of Universalism. International Review for the Sociology of Sport, 35(3), 268-281.

Spaaij, R. (2012). Olympic rings of peace? The Olympic movement, peacemaking and intercultural understanding. Sport in Society, 15(6), 761-774.

Slowikowski, S. (1991). Burning Desire: Nostalgia, Ritual, and the Sport-Festival Flame Ceremony. Sociology of Sport Journal, 8(3), 239-257.

Spiropoulos, S. (2012). Struggling to celebrate: management of the 2004 Olympic Flame Relay segment in Greece. Sport in Society, 15(5), 713-727.

Thanopoulos, M.B. (2012). American media, intercultural stories and the 2004 Olympic flame ceremonies. Sport in Society, 15(5), 728-743.

The Olympic Museum. (2007). The Olympic Flame and Torch Relay. [Online]. Available from: http://www.olympic.org/Documents/Reports/EN/en_report 655.pdf. [Accessed: $6^{\text {th }}$ March 2013]

Walker, P. \& Batty, D. (2008). Olympic torch relay cut short amid Paris protests. The Guardian. [Online]. $7^{\text {th }}$ April 2008. Available from:

http://www.guardian.co.uk/world/2008/apr/07/france.olympicgames2008. [Accessed: $6^{\text {th }}$ March 2013)

Wamsley, K.B. (2004). 'Laying Olympism to Rest'. In J.Bale \& M.K. Christensen (Eds.), Post Olympism: Questioning sport in the twenty-first century (pp. 231-242). Oxford: Berg.

Wamsley, K., \& Heine, M. (1996). Tradittion, Modernity, and the Construction of Civic Identity: The Calgary Olympics. Olympika: The International Journal of Olympic Studies, V, 81-90.

Wardle, C. \& West, E. (2004). 'The Press as Agents of Nationalism in the Queen's Golden Jubilee: How British newspapers celebrated a media event'. European Journal of Communication, 19, 195.

White, L. (2013). Cathy Freeman and Australia's Indigenous heritage: a new beginning for an old nation at the Sydney 2000 Olympic Games. International Journal of Heritage Studies, 19(2), 153-170.

Witherspoon, K. (2008). Before the Eyes of the World: Mexico and the 1968 Olympic Games. Illinois: Northern Illinois University Press.

$\mathrm{Xu}, \mathrm{X}$. (2006). Modernizing China in the Olympic spotlight: China's national identity and the 2008 Beijing Olympiad. The Sociological Review, 54(S2), 90-107.

Yalouri, E. (2010) Fanning the Flame: Transformations of the 2004 Olympic Flame. The International Journal of the History of Sport, 27(2), 2155-2183. 